\title{
The Role of Community Organizations for Place Design in Bali Aga Pengotan's Vernacular Settlements
}

\author{
Dwinik Winawangsari* Himasari Hanan Widjaja Martokusumo \\ School of Architecture, Planning and Policy Development, Institute of Technology Bandung, Bandung, \\ Indonesia
}

\begin{abstract}
The Balinese Aga Pengotan community's vernacular settlements were built by their ancestors to accommodate daily activities and ritual activities. The Pengotan community undergoes religious activities as part of their daily life, even placing religious ritual activities above everything. The Pengotan community has many ritual agendas and must be attended by all members of the community. The temple is prepared as a place to accommodate ritual ceremonies. A temple as a holy place is a collection of buildings connected by open spaces. The making of holy places is possible to happen because of the involvement of holy people in the ritual organization. This paper discusses the relationship between community organizations to maintain the continuity of the place as a place for ritual ceremonies. This behaviour research uses descriptive exploratory methods with the Observing Physical Trace (OPT) and Observing Environmental Behaviour (OEB) methods. The results show that the holy place was created and maintained for its sustainability by holy people in which the marriage institution was used by the ancestors as the guardian of the place sustainability. Through marriage, a ritual organization is formed to prepare, carry out, and supervise the course of the ritual.
\end{abstract}

Keywords: Bali Aga, vernacular settlement, place, community organization, ritual.

DOI: $10.7176 / \mathrm{ADS} / 87-05$

Publication date: November $30^{\text {th }} 2020$

\section{Introduction}

In Reuter's (2005) research, Pengotan Village is mentioned as one of the Bali Aga villages which are located close to Mount Batur. As a Bali Aga village, Pengotan has a unique socio-cultural device and is different from other villages. Pengotan village has a village government system and a typical Hindu religious ritual where a long history of village formation is the main factor affecting the village structure.

Religious life underlies all aspects of life for Pengotan residents. They follow Hindu teachings and worship their ancestors and local gods (Dwijendra, 2009). Basically, this worship aims to maintain good relations between people who are still living and the spirit world, so that their safety and welfare are well maintained.

In line with the traditions of Bali Aga village, Pengotan maintains ancestral traditions established through awig awig village and controlling the socio-religious citizens to establish an implementing body ritual or village council called dulun village or peduluan that functioned as guardians, caretakers and protectors of tradition, and customs that are carried out in Pengotan. Careful handling all matters related to sacred life, Peduluan members are selected based on the Lulu Apad system which is a characteristic of the Bali Aga village. In addition, the traditional village Pengotan has village management organization prajuru custom which is headed by a bendesa assisted by some locals/manners that have quality in leading or handling certain occupations.

A temple is a sacred place consisting of a collection of sacred buildings. Buildings in the temple area during no religious ceremonies are empty spaces without walls and furniture. Worship activities are held in open spaces that are prepared as places for ritual ceremonies. The open space is laid out in such a way that it displays a sacred place in accordance with the needs of the ritual ceremony. In an effort to form a sacred place, human involvement is needed as an element of forming a place. The elements forming the place is controlled by community organizations so that the appearance and performance of the place are in accordance with the intended ritual ceremony.

\section{Literature Review}

Vernacular settlements are human efforts to make friends with nature as their place of life. Vernacular settlements are influenced by socio-cultural aspects in which the community defines space not only as a physical element but as a place that involves various elements to make it happen, so that it meets the needs, for example, the need to worship something unseen, a place of worship is created, and so on.

The places are built according to their nature and beliefs. Shelters and settlements are formed with an arrangement that refers to sacred things. Regardless of the meaning of other factors, religion, and ritual become the main references in the formation and meaning of dwellings and settlements (Snyder and Catanese, 1984).

The form that can be found in traditional residential architecture in Indonesia is always associated with a deeper meaning, which is behind the formation that occurs and does not stop at the express or visible. Traditional houses have a significant meaning, usually describing their importance to residents, and the shape of the building 
reflects the world view of the creator (Waterson, 1990; Fox, 1966; Waterson, 1998).

Placemaking or the formation of a place is the art of making a place for humans (Sepe, 2013). The place is created for humans to be in it, enjoy the atmosphere, remember memories, and be part of the place (Wycoff and Heidel, 2012). The establishment of a place to focus on human-oriented design (Silberberg, 2013). A place has a structure created from daily activities/events carried out by individuals or groups/communities.

Montgomery (1998) in Carmona (2003) illustrates that the process of place formation occurs through activities, forms, and views. These three basic elements cannot be reduced from each other and cannot be separated in the human experience of place. However, in explaining the human experience of place, it can be identified with different focuses. Physical elements can be identified as earth, sea, sky, and the built environment, each of which offers its character for the spatial experience. The spaces are not only formed physically but also socially; thus, it influences human behaviour. Meanwhile, appearance is greatly influenced by human perceptions and tastes which influence the character of the place.

Religious ritual ceremonies are sacred and they require spaces that have a sacred meaning or sacred places. Sacred places must be created to make a sense of sacredness that humans can feel. According to Eliade (1959), a place is called sacred because there is divine power that moves the community to orient itself to that place. This divine power requires a space with a distinctive arrangement to become a sacred place for ritual activities.

The implementation of a ritual ceremony cannot be separated from the role of the actor (Koentjaraningrat, 1990). A role is a set of behaviours or actions carried out by someone as their duty and responsibility in which these actions are expected by many people (Biddle and Thomas in Sarwono, 2013). Each actor has a role in the ritual ceremony which jointly performs the function to achieve the goal. The cooperation mechanism of the actors systematically delivers the results according to the needs in the ritual ceremony. The performance of the actors can be felt by everyone who is involved in the ritual ceremony.

\section{Methods}

This research is qualitative research with a descriptive exploratory study to understand and describe the concept of a place found in Pengotan village. Exploratory research is carried out by looking at phenomena in the field, making documentation of existing conditions, observing the use of space and space in the field, and then verifying it through interviews with the space users.

Graphical data obtained from the results of recording and physical measurements were analysed using the Observing Physical Trace (OPT) method, while observations of behavioural traces were analysed using the Observing Environmental Behaviour (OEB) method developed by John Zeisel (1984). According to Zeisel, the physical environment and its surroundings are observed systematically based on the physical traces and behaviour of people towards the surrounding environment. This method is used to read the environment based on traces that are intentionally or not left behind from previous activities. Behavioural observation (OEB) is watching people interact with their environment, either alone or in groups. From these traces, researchers can conclude the process of place formation, decisions made by the actors of activities, use of space, and various information needed by researchers such as culture and how to present themselves. Observation of physical traces and behaviour relies on photos and sketches of traces that are seen because images can be very useful in analysis and reporting.

\section{Results and Discussion}

The interaction between residents forms their socio-cultural life in which their activities and behaviour are important factors in the realization of the place. Attitudes, behaviour, human activities, and values that exist in society give identity to settlements. The social and cultural life of the Pengotan community is governed by several rules in which regulate, control, and give direction to the attitudes and behaviour of citizens in social life. For the Pengotan community, these rules mean respecting the ancestors who have founded the village, which functions to ensure good relations among residents and residents with their ancestors. The realization of this good relationship is expressed in ritual ceremonies, celebratory traditions, or odalan. Ritual ceremonies for the Pengotan community are very important to be seen as a way to strengthen social relationship between individuals and the social structure of the group (social relations) and with their ancestors and gods. These ritual ceremonies must be carried out according to a predetermined time and place. These places are created to accommodate ritual ceremonies following the rules set by the ancestors.

\subsection{Placemaking Ritual}

In general, space has characters that are formed from the quality of space such as proportion and scale, path shape and pattern, texture, sound, light intensity, etc. In reality, the space used for spiritual activities has different characteristics from the common space due to the existence of a fixed point which means a lot to humans in presenting spiritual experiences. Generally, a fixed point is an object of worship in space giving the meaning of holiness and virtue where the presence of the object of worship causes holiness to spread around it (Eliade, 1959). 
A holy place is a place for community worship activities (ritual ceremonies) that residents use together at an event and in a physical setting that is following the needs of worship activities. This means that the ritual ceremony as a place filler is a major factor in the existence of a holy place that is equipped with all its accessories (settings). By identifying activities or behaviours that occur in a place, the system settings associated with the existence of elements in space will also be identified. Settings consist of space, humans, or groups as actors and their activities that represent their behaviour (Rapoport, 1997; Lawson, 2001).

The Pengotan community carries out more ritual ceremonies in open spaces. Efforts are made to provide open space that becomes a place for activities to meet the possible needs of residents by providing a space that gives satisfaction to the wearer. A holy place as a human need is a place of divinity. The Pengotan Society presents 'the one being worshiped' in two ways, namely using a statue (physical) or a non-physical one that can be felt by His presence. For example, the object of worship in the form of a Menjangan statue (Menjangan Seluang) as a tribute to Mpu Kuturan, a brahman/priest who has united three major religious groups (sects) in Bali into one understanding, namely Hinduism. Meanwhile, the object of non-physical worship is marked by the presence of offerings as a medium for encounters between gods/ancestors and their people.

To welcome the Holy One, the Pengotan community creates a festival concept at Natar Agung Pura Penataran Agung. Various symbols of holiness as decorative elements were installed, namely penjor, banners, colourful umbrellas, flags, heirloom weapons, and colourful fabrics affixed to buildings (Figure 2-a). Offerings are served as dishes, sacred line dances, dance-dramas, and shadow puppets as entertainment for gods, gods, and ancestors. Ritual ceremony attributes are placed in certain places based on the direction of the ceremony organizing committee. The entrance gate is decorated with coconut leaves as a sign of ritual ceremonial activity (Figure 2-b).

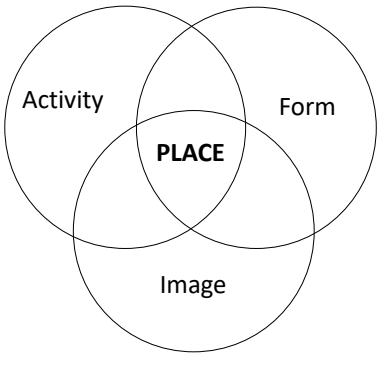

Montgomery (1998)

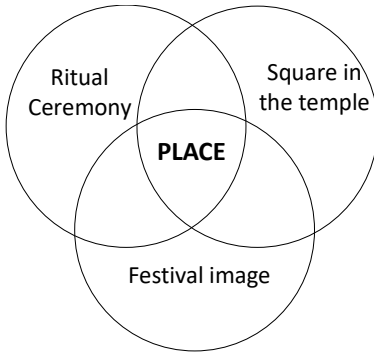

Pengotan

Figure 1. The concept of place formation by Montgomery (1998) implemented in Pengotan

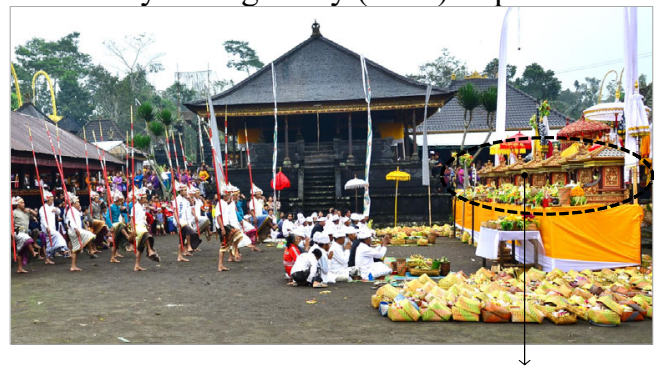

The object of worship

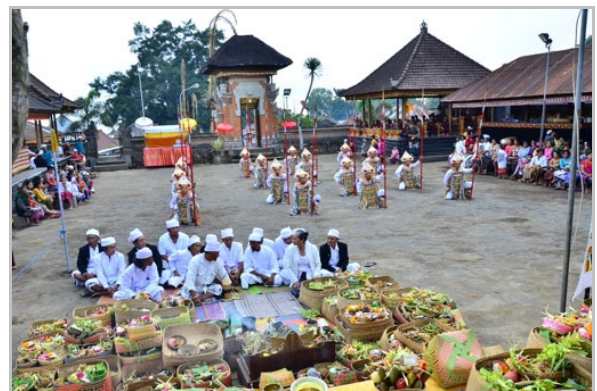

(a)

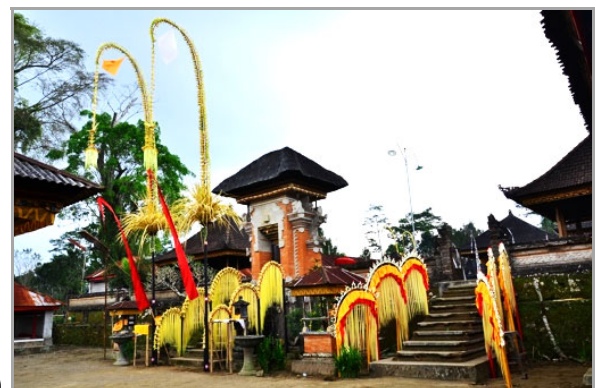

(b)

Figure 2 (a) The courtyard of the temple is prepared for a place of prayer, (b) the gate is decorated as a sign of ritual ceremonial activities

\subsection{Community organizations involved}

In village ritual ceremonies held at Pura Penataran Agung, the implementation of ritual ceremonies is manifested through the collaboration of organizations or community groups, consisting of peduluan (Gelagah 
and Bedawan) as the ritual executing body, traditional prajuru as organizers and providers of activity equipment, and manners as participants in the ritual ceremony (Figure 3). These three elements of the ritual ceremony facilitate the running of the ritual ceremony.

The agenda of the ceremony has been arranged by the peduluan and prajuru (core and main) according to the calendar of the good days in the Balinese calendar. The conditions in the village affect the implementation of village ritual ceremonies so that the ritual ceremonies do not always occur precisely according to the determination of the good day (dewasa ayu). However, with deliberation (sangkepan) between the elements organizing the ritual ceremony, problems can be resolved, and the community can participate in every ritual activity properly and get the benefits.

Professionalism is needed to be able to separate the duties in the position that are carried out with personal interests. Compared to personal and group interests, the public interest must take precedence. Kinship in the preliminary and prajuru organizations upholds honesty, strengthens the Lulu Apad system following the goal, namely that people can relate to ancestors as a force that helps in the welfare of their lives. Ritual ceremonies carried out by residents, peduluan, and prajuru adat strengthens their social or kinship relations.

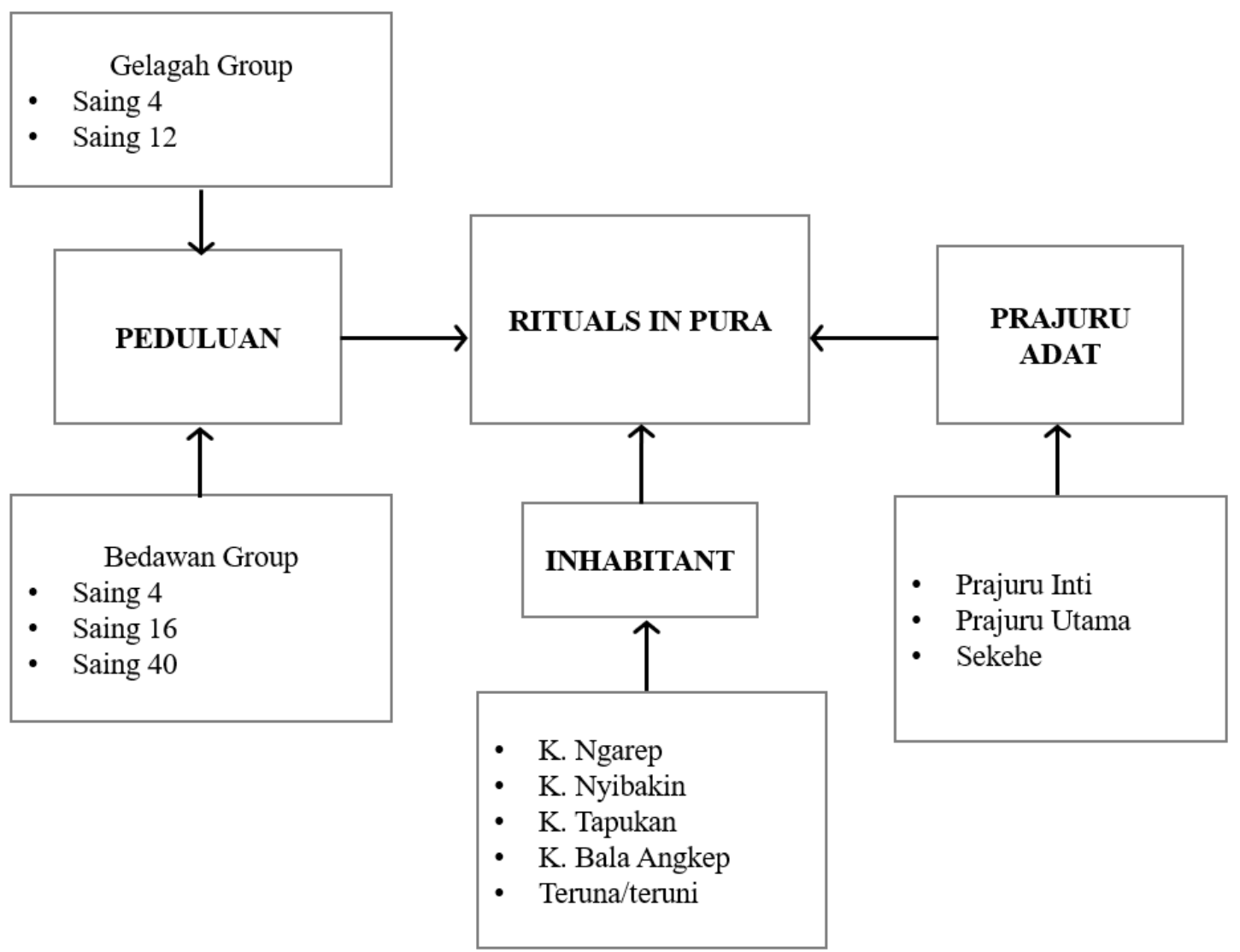

Figure 3. Social groups involved in ritual ceremonies at the Penataran Agung temple

4.3 The working mechanism of community organizations in the formation of sacred places

The division of duties in the ritual ceremony in the Pengotan community requires juniors to always learn from the seniors. On the contrary, the seniors guide their juniors, so that leadership regeneration can take place. Transfer of knowledge is prepared from a young age to become a cadet and is sharpened as long as it becomes krama. Thus, when the individual becomes a leader, his knowledge is complete. In addition, knowledge about very complex ritual ceremonies is not owned only by one person, but all citizens are prepared to accept this responsibility. The process of becoming the head of the ritual executing body (peduluan) takes a long time depending on a natural selection where death and marriage as the human life cycle determine changes and shifts in social institutions or organizations. The lulu apad system used by the Pengotan community supports the regeneration process.

Tracing the history of the formation of Pengotan village shows that residents are divided into two groups, namely Bedawan and Gelagah. This division is based on the responsibility of residents in maintaining and preserving the village temples, namely the Panti Bedawan temple and Panti Gelagah temple, and continuing the ritual tradition of the village of origin. Village founders form organizations/groups to increase the ability to carry out multiple tasks or jobs more efficiently and save time. In addition, this division of labour groups can benefit 
from the accumulated knowledge, so that the next generation can absorb the knowledge formed by the previous generation. The Pengotan community passes on knowledge from generation to generation through oral and communicated actions in the form of ritual ceremonies. Thus, the division of this group has an impact on the division of tasks, rituals/procedures in religious ceremonies, and the location of activities carried out.

Based on the history of Pengotan Village, the original inhabitants of village founders consisted of 200 heads of families known as krama ngarep. The early inhabitants were bound by the values of unity and integrity, the joys and sorrows of being shared, based on a sense of kinship (menyame beraya) which expressed togetherness and social solidarity, based on the spirit of cooperation and the principle of kinship. The division of groups based on tasks in nyungsung pura resulted in a different division of tasks carried out by the ritual executing body (peduluan), namely the ritual supervisor was the Gelagah group, while the ritual implementer was the Bedawan group. Likewise, religious rituals are related to this grouping. The residents of Bedawan and Gelagah perform rituals led by the stakeholders in their respective temple areas, but the last ritual is a prayer carried out together at Natar Agung Pura Penataran Agung. On the other hand, the two groups jointly inhabit the Customary Yard residential area without any differentiation in location.

The Lulu Apad process is the process of appointing and shifting members of the village council first in a sequential and tiered way from the lowest to the highest membership position. Lulu means "push" using the head (butting), while the word "apad" means pulled. The combination of the words lulu and apad implies that the person sitting at Bale Agung pushes with his head to occupy an earlier position. The order of the candidates for the village council members is based on their seniority in marriage. Whoever gets married first ranks above the candidate members of the village council who marry later. All the main citizens (krama ngarep) take turns according to the order of their marriage numbers, are promoted to the office, and become first members, starting from the lowest position, gradually reaching the highest position, namely competing for patpat.

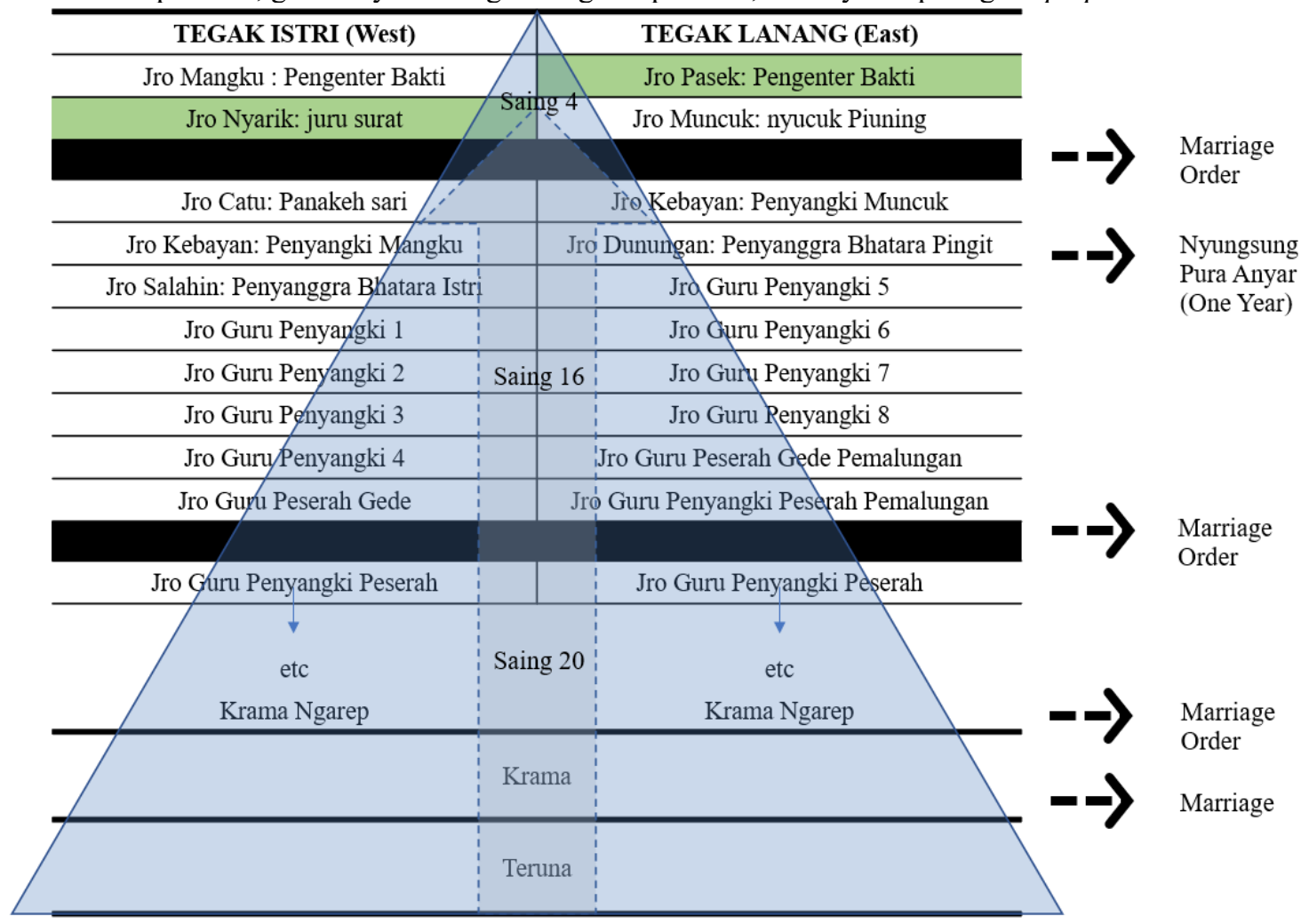

Figure 4. Hierarchy in Peduluan (Ritual Implementing Body) and Lulu Apad Process (displacement and member replacement)

Replacement of members should be decided in a plenary meeting (sangkep) which is attended by the villagers (krama). The inauguration of members of the village council or preliminaries through a ceremony held on the sixth month/sasih kanem of the Balinese calendar, while the certainty of the day of the ceremony (good day or dewasa ayu) depends on the results of the calculation of the saints or precedents. In the ritual ceremony of sasih kanem, young men (teruna) who have reached puberty (adults) perform self-purification rituals to be able to live the lives of adult humans who are responsible for preparing themselves to become manners.

4.4 The role of mass organizations for the place sustainability

Marriage and kinship are the basis for presenting and maintaining the sacred value of supernatural powers 
through ritual ceremonies. Customary organizations as executors of ritual ceremonies are formed from the idea of basic needs and human nature as social beings. The village founders realized that if basic human needs are channelled properly, activities on various scales can run smoothly and the main goal of achieving a harmonious life can be achieved. Cadets or unmarried youths have the potential (motivation) to grow and develop based on their capacities. Through marriage, they are considered as adult humans who can develop their potential and are responsible for all obligations imposed by the family and society. Through marriage, young men have more opportunities to serve Sang Hyang Widi and preserve the customs and kinship inherited from their ancestors.

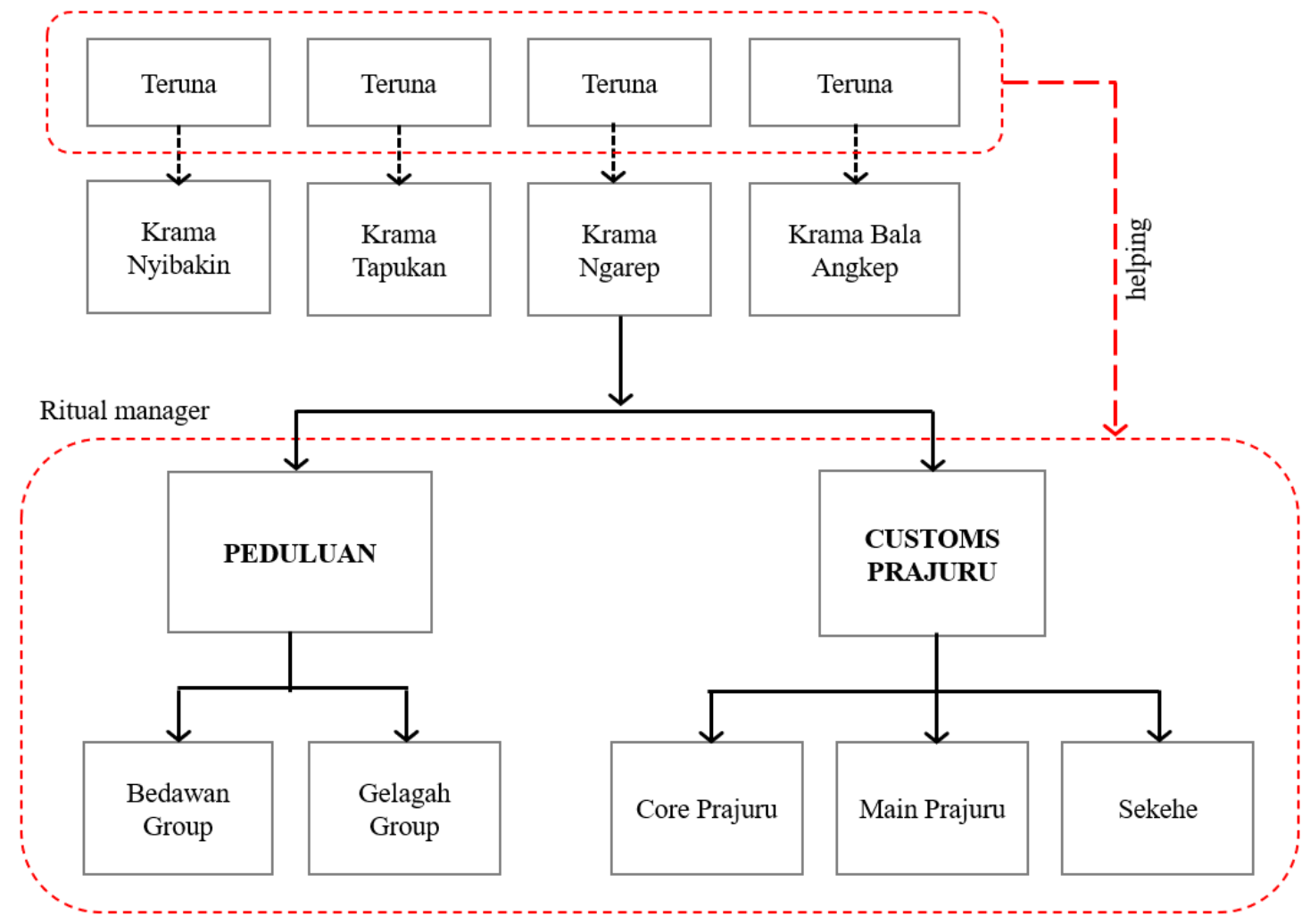

Figure 5. Ritual managers are determined because of the reasons for marriage and kinship which in turn form various roles in community organizations

\section{Conclusion}

The formation of sacred places in vernacular settlements requires the involvement of its citizens to manage and create a sense of sacred following the purpose of holding ritual ceremonies. The sense of the sacred from the place is formed by the existence of the object of worship which is the core of the formation of the sacred place which spreads the aura of holiness around it. The residents emphasize the existence of the object of worship with various symbolic attributes placed in the space which in turn displays extraordinary aesthetics.

The involvement of community organizations has an important role in shaping the place from preparing to arranging the space into a ritual place and carrying out ritual ceremonial activities. The role of each actor in the ritual had been prepared by the village founder with the aim that the relationship with the ancestors would continue for the sake of living in the future.

The village founders prepared their residents to be able to receive the relay of management and ritual management based on the journey of human life. Through marriage, every citizen is given the responsibility for building relationships with humans or groups and maintaining sustainable relationships with ancestors. It is considered a smart way to preserve the sustainability of the life of the Bali Aga community.

\section{References}

Adimastra, I. K. A. (2010): Arsitektur Bali Purba, Konsep dan Perwujudannya, Jurnal Anala, Jurnal Ilmiah Program Studi Arsitektur Fakultas Teknik Universitas Dwijendra, ISSN No, 1970- 528, edisi 6-Desember 2010, Denpasar.

Adiputra, I.G.N.T. (2016): Konsep Hulu-Teben pada Permukiman Tradisional Bali Pegunungan/Bali Aga di Desa Adat Bayung Gede Kecamatan Kintamani Kabupaten Bangli, Bali, Forum Teknik, 37, 14-31.

Afshar, A., Alaghbari, W., Salleh, E., dan Salim, A. (2012): Affordable Housing Design with Application of 
Vernacular Architecture in Kish Island, Iran. International Journal of Housing Markets and Analysis, 5, 89107.

Agusintadewi, N. K. (2016): Pola Spasial Permukiman Tradisional Bali Aga di Desa Sekardadi, Kintamani. Jurnal Review Urbanism and Architectural Studies (RUAS), Volume 14, No. 2, Desember 2016.

Alsayyad, N. (2014): The 'Real', the Hyper, and the Virtual Tradition in the Built Environment. Routledge, New York.

Ardoin, N., Schuh, M., Janel, S., Gould, dan Rachell, K. (2012): Exploring the dimensions of place: a confirmatory factor analysis of data from three ecoregional. Sites Exploring the dimensions of place: a confirmatory factor analysis of data from three ecoregional sites. Environmental Education Research, 18.

Arefi, M. (2014): Deconstructing place-making: Needs, opportunities, and assets, Abingdon, Routledge.

Arnheim, R. (2009): The Dynamics of Architectural Form, University of California Press, Berkeley.

Asquith, L. dan Vellinga, M. (editor) (2006): Vernacular Architecture in The Twenty-First Century Theory, Education and Practice, Taylor and Francis Group, London dan New York.

Bidja, I .M. (2012): Asta Kosala-Kosali Asta Bumi, Pustaka Bali Post, Denpasar.

Carmona, M., et. al. (2003): Public Place Urban Space: The Dimensions of Urban Design, Architectural Press, Oxford dan Burlington.

Castello, L. (2010): Rethinking the Meaning of Place: Conceiving Place in Architecture-Urbanism, Ashgate Publishing Limited, England.

Cuthbert, A. R. (2012): Vernacular Transformation, Context, Issues and Debates, International Joint Workshop, Universitas Udayana.

Dwijendra, N, K. A. (2012): Arsitektur Bangunan Suci Hindu, Berdasarkan Asta Kosala-kosali, CV. Bali Media Adhikarsa dan Udayana University Press, Denpasar.

Elliade, M. (1959): The Sacred and Profane, The Nature of Religion. New York: Harvest Book Harcourt, Brace \& World Inc.

Eyuce, Ahmet (2012): Interdependence of Traditional House Form and Settlement Pattern. Intercultural Understanding, volume 2, pages 17-24

Fox, Robin (1966): Kinship and Marriage, Penguin Books Ltd. Harmondsworth, England.

Friedmann, J. (2010): Place and place-making in cities: A global perspective. Planning Theory and Practice, 11 (2), 149-165. doi:10.1080/14649351003759573

Hashemnezhad, H., Yasdanfar, Abbas, S., Heidari, Akbar, A., dan Nazgol, B. (2013): Comparison the Concepts of Sense of Place and Attachment to Place in Architectural Studies. Australian Journal of Basic and Applied Sciences.

Kalb, J. (2014): Life In Design: Christopher Alexander and The Nature of Order. International Journal of Architectural Research, 8, $94-98$.

Larice, M. dan Macdonald, E. (2014): The Urban Design Reader, Routledge, New York

Lawson, B. (2001): The Language of Space, Reed Educational and Professional publishing Ltd., Oxford.

Maya in The Mountains: Ecology and Cosmology in the Rocks and Caves of Highland Guatemala dari Carleton College, Sociology and Anthropology in Guatemana and Chiapas, Field Research Paper Archives, data diperoleh melalui situs internet: https://apps.carleton.edu/curricular/ocs/guatemala/assets/Blanchard_2010.pdf. Diunduh pada tanggal 1 Oktober 2019.

Merleau-Ponty (2015): Space, Place, Architecture, Ohio University Press, Athens, Ohio.

Montgomery. (1998), Making a City: Urbanity, Vitality and Urban Design, journal of Urban Design, 3, 93-1 16.

Najafi, M. dan Kamal, M. (2011): The Concept of Place and Sense of Place In Architectural Studies. World Academy of Science, Engineering and Technology, $\mathbf{5}$.

Okoli, D.T. (2013): Sense Of Place And Student Engagement Among Undergraduate Students At A Major Public Research University, Dissertation, Colorado State University.

Peters, J. H. dan Wardana, W. (2013): Tri Hita Karana, The Spirit of Bali, Kepustakaan Populer Gramedia, Jakarta.

Pringle, R. (2005): A Short History of Bali, Indonesia's Hindu Realm, Allen \& Unwin, NSW.

Puren, K., Coetzee, H. dan Roos, V. (2010): A Hidden Dimension in Site Planning: Exploring Affective Experience as Part of Sense of Place on the Farm Kromdraai, Vredefort Dome World Heritage Site, South Africa. World Academy of Science, Engineering and Technology, International Journal of Social, Management, Economics and Business Engineering, 4.

Rapoport, A. (1997): The Nature and Role of Neighborhood, Urban Design Studies, 3, 93 - 118.

Rapoport, A. (2008): Some Further Thoughts On Culture And Environment, Archnet - IJAR, International Journal of Architectural Research, 2, 16 - 39.

Relph, E. (2013): A Pragmatic Sense of Place dari Environmental \& Architectural Phenomenology Newsletter, data diperoleh melalui situs internet: http://www.arch.ksu.edu/seamon/Relph20th.htm. Diunduh 12 
September 2014.

Rema, N. (2014): Tradisi Pemujaan Leluhur Pada Masyarakat Hindu Bali, Forum Arkeologi, 27, 1 - 12.

Reuter, T.A. (2005): Custodians of the Sacred Mountains: Budaya dan Masyarakat di Pegunungan Bali, Yayasan Obor Indonesia, Jakarta.

Rotich, D. (2012): Concept of zoning management in protected areas, Journal of Environment and Earth Science, 2, $173-183$.

Scannell, L. dan Gifford, R. (2010): Defining Place Attachment: A Tripartite Organizing Framework, Journal of Environmental Psychology, 30, 1 - 10.

Sen, A. dan Silverman, L. (2014): Making Place, Space and Embodiment in the City, Indiana University Press, Bloomington dan Indianapolis.

Sepe, M. (2016): Placemaking, Urban Identity and New Technologies, International Journal of cultural Heritage, 1, $55-64$.

Sepe, M. (2016): Placemaking, Urban Identity and New Technologies, International Journal of cultural Heritage, 1, 55 - 64 .

Snyder, James C, Anthony J. Catanese. (1984). Pengantar Arsitektur. Erlangga. Jakarta

Waterson, R. (1990): The Living House: An anthropology of architecture in South-East Asia, Oxford University Press, Singapore.

Waterson, R. (1998): The Architecture of South-East Asia through Travellers' Eyes, Oxford University Press, Kuala Lumpur.

Weber, W. dan Yannas, S. (2013): Lessons from Vernacular Architecture, Routledge, New York.

Webster, H. (2011): Bourdieu for Architects, Routledge, New York.

Widyastomo, D., Faqih, M., dan Hayati, A. (2015): Setting Transformation and The Meaning of residence in Sentani's Tribe Tradition, Humanities and Social Sciences, 3, 37 - 46.

Zeisel, J. (1981): Inquiry by Design, Cambridge University Press, New York. 